\title{
Methodical approaches to value assessment and determination of the capitalization level of high-rise construction
}

\author{
Vitaly Smirnov ${ }^{1, *}$ Leonid Dashkov ${ }^{2}$, Roman Gorshkov ${ }^{3}$, Olga Burova $^{3}$, and Alina \\ Romanova $^{4}$ \\ ${ }^{1}$ Moscow Aviation Institute (National Research University), Volokolamskoe highway, 4, Moscow, \\ 125993, Russia; \\ ${ }^{2}$ Russian University of Cooperation Moscow region, Mytischi, ul. V.Voloshina, 12/30, 141014, Russia \\ ${ }^{3}$ Moscow State University of Civil Engineering, Yaroslavskoe sh. 26, Moscow, 129337, Russia \\ ${ }^{4}$ Moscow humanitarian-economic University, Leninsky highway, 8/16, Moscow, 119049, Russia
}

\begin{abstract}
The article presents the analysis of the methodological approaches to cost estimation and determination of the capitalization level of high-rise construction objects. Factors determining the value of real estate were considered, three main approaches for estimating the value of real estate objects are given. The main methods of capitalization estimation were analyzed, the most reasonable method for determining the level of capitalization of high-rise buildings was proposed. In order to increase the value of real estate objects, the author proposes measures that enable to increase significantly the capitalization of the enterprise through more efficient use of intangible assets and goodwill.
\end{abstract}

\section{Introduction}

Under conditions of Russian economy modernization, the top priority is given to the development of methodological approaches to the parameters of the capitalization process of real estate objects. Capitalization ensures their balanced value based on reaching a consensus of economic interests of the main participants of investment and construction activities. Russian scientists assume that while implementing social programs, there is a need to reach a consensus among the main participants of investment and construction activities simultaneously, which will help to create a balanced value of housing construction projects by justifying the actual growth characteristics being the foundation of capitalization.

\section{Materials and Methods}

The cost of real estate, as well as the cost of the company is affected by a number of factors presented in Fig. 1

\footnotetext{
*Corresponding author: svgvgy@mail.ru
} 


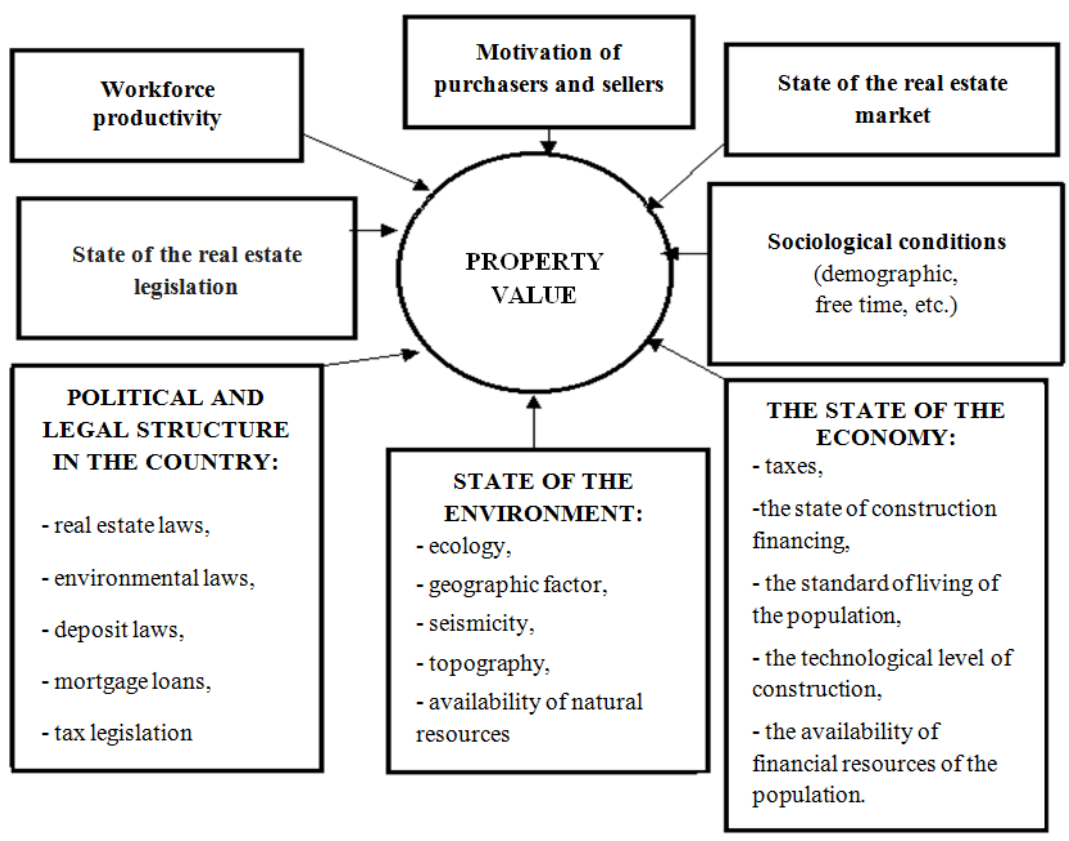

Fig. 1. Factors determining the value of real estate.

Today there is no a comprehensive methodology for assessing the capitalization of high-rise construction objects and of the entire enterprise. Theoretical and methodological issues of evaluation, which are presented in current economical scientific literature and theses, are systematized and shown in Table 1 [1].

Table 1. Methods for assessing the capitalization of enterprises and objects of real estate

\begin{tabular}{|c|c|c|c|}
\hline $\begin{array}{c}\text { Method } \\
\text { name }\end{array}$ & $\begin{array}{c}\text { Type } \\
\text { (variant) }\end{array}$ & Brief description & Formula \\
\hline \multicolumn{4}{|c|}{ Estimation of capitalization of joint-stock companies } \\
\hline $\begin{array}{l}\text { Stock } \\
\text { method }\end{array}$ & - & $\begin{array}{l}\text { Capitalization (RK) is determined through the } \\
\text { exchange value of shares }(\mathrm{P}) \text { and their quantity issued } \\
\text { by the issuer }(\mathrm{N}) \text {. }\end{array}$ & $\begin{array}{c}R K=P x \\
N\end{array}$ \\
\hline $\begin{array}{l}\text { V.V. } \\
\text { Piven's } \\
\text { method }\end{array}$ & $\begin{array}{l}\text { The multiplier } \\
\text { of market } \\
\text { capitalization }\end{array}$ & $\begin{array}{l}\text { Shows the amount of changes in the capitalization } \\
(\Delta \mathrm{MS}) \text { resulting from the purchase and sale of stocks. }\end{array}$ & $\begin{array}{c}M M S= \\
\Delta M S / S\end{array}$ \\
\hline \multicolumn{4}{|c|}{ Estimation of capitalization of other enterprises } \\
\hline \multirow[t]{3}{*}{$\begin{array}{l}\text { The } \\
\text { multiplier } \\
\text { method }\end{array}$} & & $\begin{array}{l}\text { The algorithm of the method is reduced to two stages: } \\
\text { - at the first stage, the multiplier coefficient (k) is } \\
\text { calculated, characterizing the dependence of } \\
\text { capitalization on profit, sales volume, assets and other } \\
\text { parameters of financial and economic activity; } \\
\text { - at the second stage, the capitalization (C) of the } \\
\text { evaluated enterprise is calculated on the basis of its } \\
\text { parameters (FP) for profit, sales volume, assets and } \\
\text { multiplier coefficient }\end{array}$ & $\begin{array}{c}C=\boldsymbol{k} \\
\boldsymbol{F P}\end{array}$ \\
\hline & $\mathrm{P} / \mathrm{E}$ ratio & $\begin{array}{l}\mathrm{P} / \mathrm{E} \text { ratio is the quotient of dividing the capitalization } \\
\text { of the enterprise by their net profit. The capitalization } \\
\text { of the i-th enterprise is the product of the } \mathrm{P} / \mathrm{E} \text { ratio by } \\
\text { its net profit. }\end{array}$ & $\begin{array}{c}C=\boldsymbol{k} \\
\boldsymbol{P}_{\text {net }}\end{array}$ \\
\hline & $\mathrm{P} / \mathrm{R}$ ratio & $\mathrm{P} / \mathrm{R}$ ratio is the quotient of dividing the capitalization & $C=k *$ \\
\hline
\end{tabular}




\begin{tabular}{|c|c|c|c|}
\hline & & $\begin{array}{l}\text { of enterprises by their sales volume. The } \\
\text { capitalization of the i-th enterprise is the product of } \\
\text { the } \mathrm{P} / \mathrm{R} \text { ratio by its sales volume (V) or proceeds from } \\
\text { the sale of goods, works, services }\end{array}$ & $V$ \\
\hline & $\mathrm{P} / \mathrm{NAV}$ ratio & $\begin{array}{l}\text { P/NAV ratio is the quotient of dividing the } \\
\text { capitalization of enterprises by their net assets. The } \\
\text { capitalization of the i-th enterprise is the product of } \\
\text { the P/NAV coefficient on its net assets }\left(\mathrm{A}_{\text {net }}\right) \text { or } \\
\text { proceeds from the sale of goods, works, services }\end{array}$ & $\begin{array}{c}C=\boldsymbol{k}^{*} \\
\boldsymbol{A}_{n e t}\end{array}$ \\
\hline & $\mathrm{P} / \mathrm{BV}$ ratio & $\begin{array}{l}\text { The P/BV ratio is the quotient of dividing the } \\
\text { capitalization of enterprises by their balance currency } \\
\text { (book value). The capitalization of the i-th enterprise } \\
\text { is the product of the } \mathrm{P} / \mathrm{BV} \text { ratio at its book value ( } \mathrm{C} \\
\text { bal) }\end{array}$ & $\begin{array}{c}C=\boldsymbol{k} \\
C_{b a l}\end{array}$ \\
\hline & $\mathrm{P} / \mathrm{BVA}$ ratio & $\begin{array}{l}\mathrm{P} / \mathrm{BVA} \text { ratio is the quotient of dividing the } \\
\text { capitalization of enterprises by their balance currency } \\
\text { (book value). The capitalization of the i-th enterprise } \\
\text { is the product of the } \mathrm{P} / \mathrm{BVA} \text { ratio on its balance } \\
\text { currency }\left(\mathrm{B}_{\text {bal }}\right)\end{array}$ & $\begin{array}{c}C=\boldsymbol{k} \\
\boldsymbol{B}_{b a l}\end{array}$ \\
\hline $\begin{array}{l}\text { Method } \\
\text { of } \\
\text { capitali- } \\
\text { zation }\end{array}$ & $\begin{array}{l}\text { A.G. } \\
\text { Berberyan's } \\
\text { method }\end{array}$ & $\begin{array}{l}\text { The reference value of the } \mathrm{P} / \mathrm{E} \text { ratio is taken equal to } \\
20 \text {. Then the capitalization of the enterprise is equal } \\
\text { to } 20 \text { volumes of its net profit with an adjustment for } \\
\text { the coefficient of variation ( } \mathrm{k}_{\mathrm{var}} \text { ), which is determined } \\
\text { by the set of counted elements estimated in points }\end{array}$ & $\begin{array}{c}C= \\
=20 * P_{\text {net }} \\
* * k_{\text {var }}\end{array}$ \\
\hline $\begin{array}{l}\text { Ratio of } \\
\text { capitali- } \\
\text { zation }\end{array}$ & $\begin{array}{l}\text { A.V. } \\
\text { Bubnova's } \\
\text { method }\end{array}$ & $\begin{array}{l}\text { The coefficient of capitalization is a quotient of the } \\
\text { division of the market value of equity capital to the } \\
\text { book value of borrowed capital }\end{array}$ & $\begin{array}{c}C_{\text {cap }}= \\
=E C \\
\text { mark } / B C \\
\quad \text { bal }\end{array}$ \\
\hline $\begin{array}{l}\text { Methodo- } \\
\text { logy of } \\
\text { rating } \\
\text { evaluatio } \\
\quad n\end{array}$ & $\begin{array}{l}\text { Y.S. } \\
\text { Karpuzov's } \\
\text { method }\end{array}$ & $\begin{array}{l}\text { The procedure includes } 7 \text { stages: } \\
\text { 1. construction of a dynamic series of absolute } \\
\text { indicators; } \\
\text { 2. express diagnostics of absolute indicators, } \\
\text { 3. Calculation of relative indicators of the dynamics } \\
\text { of capitalization; } \\
\text { 4. comparison of the results with the criterial values } \\
\text { of dynamic capitalization; } \\
\text { 5. rating assignment by the dynamics of accumulated } \\
\text { capitalization; } \\
\text { 6. rating description; } \\
\text { 7. ranking of enterprises by the dynamics of } \\
\text { capitalization }\end{array}$ & - \\
\hline Goodwill & $\begin{array}{l}\text { N.S. } \\
\text { Pogorelova's } \\
\text { method }\end{array}$ & $\begin{array}{l}\text { The method of surplus profits, which is based on the } \\
\text { fact that they bring intangible assets unreflected in the } \\
\text { balance sheet, which provide yield on assets and on } \\
\text { equity capital above the industry average. } \\
\text { 1. Calculation of the value of all company assets } \\
\text { 2. Adjustment to obtain a normalized net profit. } \\
\text { 3. Determination of the average branch index of } \\
\text { return on assets } \\
\text { 4. Definition of expected profit. } \\
\text { 5. Calculation of surplus profits, which include the } \\
\text { impact of goodwill. } \\
\text { 6. Calculation of the value of goodwill. }\end{array}$ & - \\
\hline
\end{tabular}

Capitalization of a real estate object reflects an increase in its value, therefore the concept of capitalization is directly related to the concept of value. 


\section{Results}

The value management of real estate objects and construction companies implies the creation of positive cash flows. This management is most effective when the following management methods are combined:

1) financial, which are based on the discounted cash flow model (DCF);

2) non-financial (they include the balanced scorecard model (BSC)).

There are three main approaches for estimating the value of real estate objects and enterprise for determination of the level of the company capitalization:

\section{Income approach}

\section{A. Discounted cash flow method}

Today at almost all enterprises, the analysis of new investments (real investments) is based on the discounted cash flow method, which fully corresponds to the valuation of stocks, which is equal to the discounted value of future cash flows expected by stockholders at any given moment. The DCF method is reasonable to apply for a large enterprise, because it enables taking into account the risks related to the uncertainty of the activities. This method is also suitable for those enterprises where the financial situation depends on the contracts completed [2].

The discounted cash flow method consists of several stages:

1. Choosing the cash flow model. When assessing the value of an enterprise, one of two models of cash flow is used: for net worth and total invested capital.

2. The retrospective analysis and the forecast of gross proceeds from sales require detailed consideration of the following factors: production volumes, enterprise growth rates, available production capacities, prospects and possible consequences of capital investments, the general situation in the economy, the share of the estimated enterprise on the market, long-term growth rates of the enterprise [3].

3. Analysis and forecast of costs, which can be divided into production (operating) costs and capital costs (investment costs, which are aimed at extensive and intensive development of production). Accounting for production costs and capital expenditures shows their impact on the value of the enterprise at various stages of the LC [4].

4. Analysis and forecast of investments, including analysis of own working capital, analysis of capital investments and analysis of the need for financing

5. Calculation of the cash flow for each year of the forecast period. There are two main methods: the direct method, which is based on the analysis of cash flow by items of income and expenditure, i.e. on accounting accounts; the indirect method, which analyzes the cash flows by the directions of business.

6. Determination of the discount rate.

Due to the risk associated with obtaining future income, the discount rate should exceed the rate of risk-free investments and provide additional income for the entire period of risk.

7. Calculation of the value of business in the post-forecast period. In the post-forecast period, the calculation of the discount rate should be made using the Gardon method, which is based on the forecast of obtaining stable incomes in the residual period and implies the equality of the amount of depreciation and capital investments [5].

$$
P V=D_{n} * \frac{1+g}{(R-g)},
$$

were $R_{v}=\mathrm{PV}$ is for residual value of the enterprise (reversion) in the post-forecast period, $D_{n+1}=D_{n} *(1+g)$ is for income that can be gained within the first post-forecast year $\left(D_{n+1}\right), g$ is for expected annual growth rates of income, $\mathrm{R}$ is the coefficient of capitalization. 
9. The calculation of the present value of future cash flows and the value within the post-forecast period is the summation of the present value of periodic cash flows and the current value in the post-forecast period expected in the future.

10. Final amendments. After determining the preliminary value of the enterprise cost, there is a need to make final adjustments to the value of the non-performing assets and adjust the value of the working capital in order to obtain the final market value [6].

B. Income capitalization method

It is applied when insignificant fluctuation of the future incomes is expected. According to this method, the value is determined by dividing the results of activity (profit or cash flow) for the base period by the capitalization ratio.

\section{Cost approach}

A. Method of net assets.

The general formula for estimating a company using the net assets method is:

$$
\mathrm{NAV}=\Sigma \mathrm{VAi}-\mathrm{D}+\mathrm{G}, \mathrm{i}=1 \text {, }
$$

Where, NAV is the value of the company's net assets; VAi is the market value of $i^{\text {th }}$ asset; $D$ is market value of obligating documents; $G$ is goodwill. As it can be seen from the formula, firstly, the company's assets disclosed in the balance sheet are corrected for their market valuation, then the market value of obligating documents is deducted and the value of goodwill is added.

\section{B. Residual value method}

Liquidation value is the value that is obtained when the enterprise is liquidated and a separate sale of assets is possible. The evaluation formula is:

$$
\mathrm{LV}=\mathrm{PV}(\Sigma \mathrm{AVi})-\mathrm{D}-\mathrm{CL}, \mathrm{i}=1
$$

where LV is the liquidation value of the company; AVi is the value of the $i^{\text {th }}$ asset; D is market value of obligating documents; $\mathrm{CL}$ is the cost of liquidating the company.

\section{Comparative (market) approach}

A. Capital market method

This method is based on market prices of stocks of comparable companies that are listed on the stock market.

\section{$B$. The method of transactions}

This method is based on the analysis of prices, the acquisition of control stocks of comparable enterprises or the analysis of the acquisition prices of enterprises in whole.

\section{Sectoral coefficient method}

- This method is used for an approximate valuation of enterprises. This methos consists in analysis of large statistical data of specific transactions on sales of enterprises

\section{Discussions}

Particular attention in assessing the value of real estate objects and an enterprise should be paid to modern approaches to assessing the business reputation (goodwill) of the company. A professional valuation of goodwill will help to reveal the real value of the business and, in particular, sell it at a much higher price.

Today there are no decisive methods to calculate accurately reputational assets. Studies made by domestic scientists show that a change in reputation by $1 \%$ leads to a change in market value of $3 \%[7]$.

For construction companies, the reputation is especially important due to industry specific features: high production costs, multi-level risks, duration of the technological cycle, etc. Buyers usually carefully choose real estate. They study the market, the quality of products, the reputation of a company. In this context, the reputation of the construction company is the key to its success, 
so the management should pay special attention to the key factors shaping the reputation: the success and experience of a company, the openness and transparency of business operations and financial matter, private trust to the first persons of a company, social responsibility and others.

\section{Conclusion}

First of all, the reputation is developed by the fulfillment of the obligations assumed: the deadlines for delivery of objects and the quality of construction. Elaboration of houses and proper planning of apartments, which ensures comfortable living, also play an important role. The conclusion from the above is that capitalization is a complex process of increasing the value of enterprises through various sources: retained income, revaluation of assets, increase in the value of stocks, etc. Today construction companies pay insufficient attention to issues related to their capitalization, especially through intangible assets and goodwill.

\section{References}

1. V. Pukhkal, V. Murgul, M. Garifullin Procedia Engineering 117 624-627 (2015)

2. R. Golov, V. Shilov, S. Silantiev ASEE International Forum, Columbus, Ohio. Paper ID \#20766. (2017)

3. V. Kankhva, Procedia Engineering $165 \quad 1300-1304 \quad$ (2016) doi:10.1016/j.proeng.2016.11.855

4. A. Jones, G. Fallon, R. Golov European Business Review, 12-4, pp.187-197, doi. $10.1108 / 09555340010336871$

5. A. Bril, O. Kalinina, O. Valebnikova, Lecture Notes in Computer Science, 9870, pp 766-775 (2016) DOi -10.1007/978-3-319-46301-8_67

6. A.K. Orlov, I.Y. Chubarkina MATEC Web of Conferences 10608015 (2017)

7. I.V. Ilin, A. Lepekhin, A.I. Levina, O.Yu. Iliashenko, Advances in Intelligent Systems and Computing, 692, pp 1306-1314 (2018) DOi -10.1007/978-3-319-70987-1_138 